\title{
Study on the Distribution Characteristic and Engineering Behavior of Moraine Layers in Northwest Yunnan
}

\author{
Chun-yang Chai ${ }^{1, a^{*}}$, Xi-yong Wu ${ }^{1, b}$, Guang-ze Zhang ${ }^{2, c}$ \\ ${ }^{1}$ Southwest Jiaotong University,Chengdu Sichuan ,610031,China; \\ ${ }^{2}$ China Railway Eryuan Engineering Group Co.Ltds,Chengdu Sichuan, 610031 ,China. \\ a37101835@qq.com, bwuxingyong@126.com, '252897727@qq.com
}

Keywords: Northwest Yunnan; Glaciation; ice moraine layer; Distribution characteristic; Engineering characteristic

\begin{abstract}
Northwest Yunnan had experienced glaciation many times since the quaternary. Moraine layers are fragmentary material and loose deposits produced by glacial erosion in the early and interglacial periods. It is characterized by the complex composition, uneven grain composition and disordered structure, etc. In this paper, based on the construction of Lijiang to Shangri-la railway, the distribution and class of the moraine layer in Northwest Yunnan were investigated in the field. On the basis of indoor and in-situ tests, the particle composition, degree of consolidation, physical and mechanical properties of moraine layer were mainly studied. The moraine layer foundation strength and slope stability were evaluated comprehensively. The research provided scientific basis to the engineering scheme and measures. It is significant for engineering surveys, designs and constructions of the moraine layer in northwest Yunnan. It also provided references for Sichuan-Tibet railway and the Yunnan-Tibet railway construction.
\end{abstract}

\section{Introduction}

Haba Snow Mountain and Jade Dragon Snow Mountain are located in the northwest of Yunnan province, middle of HengDuan Mountains of the south east edge of Qinghai-Tibet plateau. The topography is north west to south east low in the ground. Since the quaternary period, due to glaciers action, moraine layers were distributed among foothills and valleys along both sides of snow mountains. Roads and railways are mostly built along the foothills and pass the moraine layers for multiple times. The characteristics of moraine layers including complex composition, uneven grain composition and disordered structure significantly influence designs, constructions and safety in engineering operations. At present, the research of the moraine layers mainly concentrates on the quaternary geology, ice frozen soil, climatology and hydrogeology, seldom on studying the engineering properties of moraine layer ${ }^{[1]}$.

The glacier has unique characteristics of erosion, transportation and deposition. With the influence of geological structures and climate environment, the engineering characteristics of moraine layers in different areas have relatively huge differences. Based on the field investigation and test data in Lijiang to Shangri-la railway, it introduced the formation age, distribution feature, material composition, grain composition, degree of consolidation and physical-mechanical properties. What's more, it analyzed the distribution characteristics and the possible geological problem of moraine layers.

\section{The era and distribution characteristics of moraine layer}

Since the middle and the late Pleistocene, the study area experienced four ice ages, and in turn, they are Jade Dragon Ice age (0.7-0.6 MaB.P), Dry Haizi Ice age (0.53-0.45 MaB.P), Lijiang Ice 
age (0.31-0.13 MaB.P) and Dali Ice age (25000-18000 aB.P $)^{[2]}$. The study area formed multiphase glacial deposits. Under the joint action of the new tectonic movement and glacier activities, the Qinghai-Tibet plateau rose rapidly and alpine snowline increase rapidly. Meanwhile the glaciation decreased. During this period, due to the fractures, various types of basin caused by fractures developed fault block mountains and multistage denudation platform ${ }^{[3-4]}$, result in Lead to glacial landforms and glacial till diversification, complicated. Based on the field investigation and former achievements, the distribution of moraine layers are divided into three types: depression, terrace, replat.

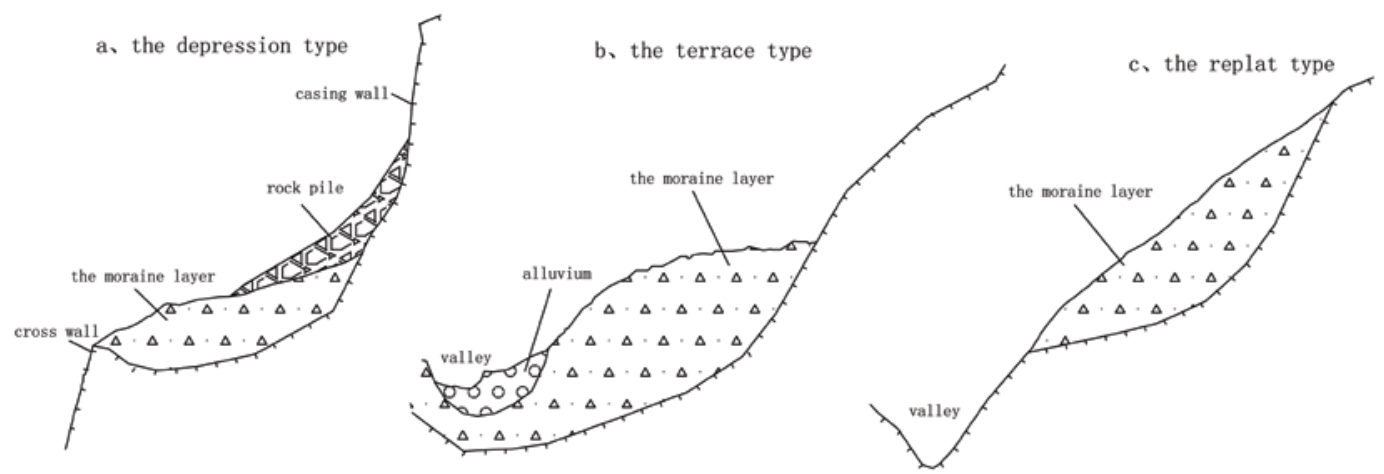

Fig 1 the marine layer distribution of the three types

The depression type is formed by cirque degradation. Cirque is in round-backed armchair shape, with three steep cliffs on the back side, an opening to the downhill and a threshold at the bottom of the opening. Cirque often developed around the snowline. With the continuously rise of snow line, the cirque distributes in different altitudes. The bottom of old cirque which is located in relatively low altitudes was filled with material transported by the later glacial. With the weathering and denudation, the casing and cross-wall would be converted into irregular shapes. Loose gravel commonly piled up in the slope toe. According to the field investigation, the moraine layer has a round-backed armchair distribution, and there are steep cliffs on the back side and a scarp on the front side, which has a landform type similar to the landslide, and the biggest difference between cirque and landslide was that the bedrock is exposed at the scarp of leading edge of moraine layers. Besides, the bottom of cirque was deeply concaved, and there is a slope reversed threshold at the opening, which are good for the overall stability of the moraine layer.

The terrace type consists of piedmont glacier accumulation. During the Jade Dragon Ice age and Dry Haizi Ice age, tectonic uplift movement forced the mountain move over the snow line. During that period, the ground of the area had a relatively low incision degree, and abundant rainfall happened because of the summer monsoon effect. Huge piedmont glaciers developed in the area and moraine deposited in valley and basin. Along the continual tectonic uplift movement and river incision, multistage erosion terrace developed in the moraine layer. A large area of moraine layer was found in the terrace between Sanjia village to Dukou village on the east bank of the Chin-sha River. The length and width of the layer are $6 \mathrm{~km}$ and $1.5 \mathrm{~km}$ respectively, and $300 \sim 400 \mathrm{~m}$ higher than the river ${ }^{[5]}$. The moraine layer of the terrace type has a zonal distribution and a large scale, which is different from common terrace. This kind of terrace is poorly sorted and has no cyclothem in it.

The replat type consists of valley glacier accumulation. In middle-late Pleistocene, after a strong tectonic uplift movement, steep mountains and deep valley developed. During Lijiang Ice age and Dali Ice age, the range of high mountains over the snow line reduced. The glacier was less active, and valley glacier was in domination. Moraines deposited in the valley, and formed several lateral moraine dams and terminal moraine ridge. Because of the uplift of the mountain and the incision of the river, lateral and terminal moraines were left on the replat, with bed rock of meters or tens of meters underlay. Generally, the replat type moraine is relatively small scaled. In the later weathering denudation, moraine landform disappeared. In addition, vegetation in the area is well developed, which makes it hard to be aware of the layer in the field investigation. 


\section{Rock and soil types of moraine layers}

Moraine layer is debris produced by glacial erosion effect and loose deposits of early and interglacial glacier. According to material composition, grain composition and cementation degree, moraine layers of the study area can be divided into breccia and gravel soil.

Breccia whose parent rocks is mainly composed of carbonatite including limestone and marble. The breccia has a frame structure consists of clastic and rock blocks, less argillaceous material and high degree of consolidation. According to the indoor XDR test, the main mineral composition of cement is calcite, a small amount of quartz and clay minerals. The accounts of calcite can reach more than $90 \%$ of the total cement content ${ }^{[6]}$. Under the action of ice and snow melt water, atmospheric precipitation and the seepage, dissolution and precipitation of the groundwater, carbonatite turns the loose crushed stones into calcarinate breccia.

The gravel mixed soil, according to the results of grain size analysis, as shown in table 1, has the feature that the curve is high in the middle and low on both sides. Coarse grain is mainly gravel breccia, which accounts about 32.1 45.6\%. Parent rock composition are mainly basalt, slate, and a small amount of limestone. Fine grained material is mainly clay, which accounts about 32.7 48.7\%. The composition is mainly fully weathered basalt, mud-filled and calcic-filled materials. Mineral analysis result shows that the composition of the fine gained material is mainly illite, a small amount of kaolinite and chlorite. The account of illite can reach 93\%. Due to the high content of clay in the mixed soil, most of the crushed stones are suspending in the fine grained soil individually, and unable to form a frame structure. However clay minerals can form a bit of cohesive force. In addition, the non-uniform coefficient of the soil (cu) is $425 \sim 2667$, and the curvature coefficient is $0.0015 \sim 0.002$, which shows that the particle distribution of soil is very poor.

In addition, during the glacial and interglacial period, the climate was mainly warm and humid ${ }^{[2}$, 7]. Under hot and humid circumstances, weather crust is likely to form. The ancient weathering crusts were folded in the underside of moraine layers, or between the moraine layers, which are mainly hard plastic shaped reddish brown, brown cohesive soil, with a thickness of $0.5 \sim 1 \mathrm{~m}$.

Table.1 article analysis results if soil sample

\begin{tabular}{|c|c|c|c|c|c|c|c|c|c|c|c|c|}
\hline \multirow{2}{*}{ No } & \multicolumn{7}{|c|}{ Percentage of specify particle size（\%） } & \multirow{2}{*}{$\begin{array}{c}\begin{array}{c}\text { Average } \\
\text { particle } \\
\text { size }\end{array} \\
\mathrm{d}_{50} / \mathrm{mm}\end{array}$} & \multirow{2}{*}{$\begin{array}{c}\text { Controlli } \\
\text { ng } \\
\text { particle } \\
\text { size }\end{array}$} & \multirow{2}{*}{$\begin{array}{c}\text { Effectiv } \\
\text { e } \\
\text { controlli } \\
\text { ng } \\
\text { particle } \\
\text { size } \\
\mathrm{d}_{10} / \mathrm{mm}\end{array}$} & \multirow{2}{*}{$\begin{array}{c}\text { the } \\
\text { non-unif } \\
\text { orm } \\
\begin{array}{c}\text { coefficie } \\
\text { nt }\end{array} \\
\mathrm{Cu}\end{array}$} & \multirow{2}{*}{$\begin{array}{c}\text { the } \\
\text { curvat } \\
\text { ure } \\
\text { coeffic } \\
\text { ient } \\
\text { Ce }\end{array}$} \\
\hline & 20 & 5 & 2 & 0.5 & $\begin{array}{c}0.2 \\
5\end{array}$ & $\begin{array}{c}0.07 \\
5\end{array}$ & 0.005 & & & & & \\
\hline P1 & $\begin{array}{c}80 . \\
3\end{array}$ & $\begin{array}{c}67 . \\
8\end{array}$ & $\begin{array}{c}58 . \\
1\end{array}$ & $\begin{array}{c}49 . \\
8\end{array}$ & $\begin{array}{c}46 . \\
6\end{array}$ & 41.3 & 21.2 & 0.45 & 2.2 & 0.0016 & 1375 & 0.048 \\
\hline P2 & $\begin{array}{c}88 . \\
5\end{array}$ & $\begin{array}{c}74 . \\
2\end{array}$ & $\begin{array}{c}64 . \\
3\end{array}$ & $\begin{array}{c}55 . \\
1\end{array}$ & $\begin{array}{c}51 . \\
7\end{array}$ & 45.7 & 22.7 & 0.18 & 1 & 0.0017 & 588 & 0.048 \\
\hline P3 & 91 & $\begin{array}{c}76 . \\
4\end{array}$ & $\begin{array}{c}66 . \\
9\end{array}$ & $\begin{array}{c}57 . \\
3\end{array}$ & $\begin{array}{c}54 . \\
2\end{array}$ & 48.7 & 24.1 & 0.1 & 0.68 & 0.0016 & 425 & 0.063 \\
\hline P4 & 91 & $\begin{array}{c}69 . \\
3\end{array}$ & $\begin{array}{c}55 . \\
4\end{array}$ & $\begin{array}{c}42 . \\
7\end{array}$ & $\begin{array}{c}38 . \\
7\end{array}$ & 32.7 & 17.2 & 1 & 2.8 & 0.002 & 1400 & 0.161 \\
\hline P5 & $\begin{array}{c}71 . \\
1\end{array}$ & $\begin{array}{c}61 . \\
7\end{array}$ & $\begin{array}{c}54 . \\
4\end{array}$ & $\begin{array}{c}47 . \\
9\end{array}$ & $\begin{array}{c}45 . \\
6\end{array}$ & 41.8 & 24.1 & 0.7 & 4 & 0.0015 & 2667 & 0.011 \\
\hline P6 & $\begin{array}{c}95 . \\
6\end{array}$ & $\begin{array}{c}80 . \\
7\end{array}$ & $\begin{array}{c}67 . \\
9\end{array}$ & $\begin{array}{c}55 . \\
1\end{array}$ & $\begin{array}{c}50 . \\
6\end{array}$ & 43.1 & 21.4 & 0.22 & 0.72 & 0.0016 & 450 & 0.087 \\
\hline P7 & $\begin{array}{c}92 . \\
1\end{array}$ & $\begin{array}{c}73 . \\
4\end{array}$ & $\begin{array}{c}59 . \\
1\end{array}$ & $\begin{array}{c}47 . \\
9\end{array}$ & $\begin{array}{c}44 . \\
3\end{array}$ & 37.7 & 19.7 & 0.56 & 2.2 & 0.0015 & 1467 & 0.121 \\
\hline
\end{tabular}




\section{Physical and Mechanical properties of moraine layers}

\subsection{Physical properties}

From the physical test result, the natural average density of breccia is $2.38 \mathrm{~g} / \mathrm{cm}^{3}$ and the average porosity is $12.4 \%$, which is $3 \sim 5$ times higher than the common rock. This result suggests that the accumulation of glacial tilled is disorganized, cemented together in the late calcification. The rock always has a frame structure, which leads to a higher block bibulous rate (2.02 5.93\%). Generally, the higher the water absorption of the rock is, the worse the degree of consolidation is. However, after submerged in water for $24 \mathrm{~h}$, most of the samples are not moldered. Only a small amount of the cemented material came off, which shows that water has a very limited influence on the calcium cementation, and the breccia has a good water stability for the cementation material. The moisture content and density of gravel mixed soil are significant inhomogeneity. The different value between maximum and minimum water content value was about $6 \%$. The maximum dry density was about $2.47 \mathrm{~g} / \mathrm{cm}^{3}$, and the minimum was only $1.80 \mathrm{~g} / \mathrm{cm}^{3}$. The different value is as high as 0.6. Void ratio was $0.16 \sim 0.59$, which is lower than the average in hard plastic clay. The Void ratio indicates that the permeability was very poor. According to the liquid-plastic limit test of fine grained soil, the liquid limit has an average value of $41.6 \%$. The plasticity index has an averages value of 19.2, and the active index is 1.5 , which suggests that the fine grained soil had a strong water imbibition, yet the gravel mixed soil has a poor water stability.

Table. 2 physical test in the moraine layer

\begin{tabular}{|c|c|c|c|c|c|c|c|c|c|c|}
\hline \multirow[b]{2}{*}{ No } & \multicolumn{4}{|c|}{ breccia $^{[6]}$} & \multirow[b]{2}{*}{ No } & \multicolumn{5}{|c|}{ Gravel mixed soil } \\
\hline & $\begin{array}{l}\text { density } \\
\mathrm{g} / \mathrm{cm}^{3}\end{array}$ & $\begin{array}{c}\text { Poros } \\
\text { ity } \\
\%\end{array}$ & $\begin{array}{c}\text { water } \\
\text { absorption } \\
\%\end{array}$ & $\begin{array}{c}\text { Water } \\
\text { stability }\end{array}$ & & $\begin{array}{l}\text { density } \\
\mathrm{g} / \mathrm{cm}^{3}\end{array}$ & $\begin{array}{c}\text { water } \\
\text { content } \\
\%\end{array}$ & $\begin{array}{c}\text { Dry } \\
\text { density } \\
\mathrm{g} / \mathrm{cm}^{3}\end{array}$ & $\begin{array}{c}\text { gravi } \\
\text { ty }\end{array}$ & $\begin{array}{l}\text { Void } \\
\text { radio }\end{array}$ \\
\hline E142 & 2.33 & 13.70 & 4.20 & stable & PT1 & 2.15 & 15.3 & 1.86 & 2.86 & 0.54 \\
\hline E148-1 & 2.34 & 13.33 & 2.02 & stable & PT2 & 2.35 & 16.3 & 2.03 & 2.86 & 0.41 \\
\hline $\begin{array}{c}\text { SQB68- } \\
2\end{array}$ & 2.3 & 15.75 & 5.93 & $\begin{array}{c}\text { Less } \\
\text { stable }\end{array}$ & PT3 & 2.23 & 12.8 & 1.98 & 2.86 & 0.45 \\
\hline SQ047 & 2.49 & 10.11 & 2.19 & stable & PT4 & 2.08 & 16 & 1.80 & 2.86 & 0.59 \\
\hline E077-1 & 2.43 & 10.00 & 2.46 & stable & PT5 & 2.17 & 18.9 & 1.82 & 2.86 & 0.57 \\
\hline E077-2 & 2.39 & 11.48 & 3.84 & stable & PT6 & 2.85 & 15.6 & 2.47 & 2.86 & 0.16 \\
\hline
\end{tabular}

\subsection{Mechanical properties}

\subsubsection{Mechanical test for breccia}

Complete samples were taken for uniaxial and triaxial compression test. According to the results of uniaxial compression test, breccia specimens mainly generated shear failure along the gravel particles clearance, and the failure surface is a slow wave structure, the uniaxial compressive strength is $10.94 \sim 14.22 \mathrm{Mpa}{ }^{[6]}$. Based on the triaxial compression test data, the strength of the rock mass envelope diagram was drawn, as shown in figure 2. It is concluded that the breccia cohesion C is $3.3 \mathrm{Mpa}$, internal friction Angle $\varphi$ is $31.27^{\circ}$. The elastic modulus of the rock is $20 \sim$ $25 \mathrm{Gpa}$, and poisson's ratio is $0.15 \sim 0.23$. 


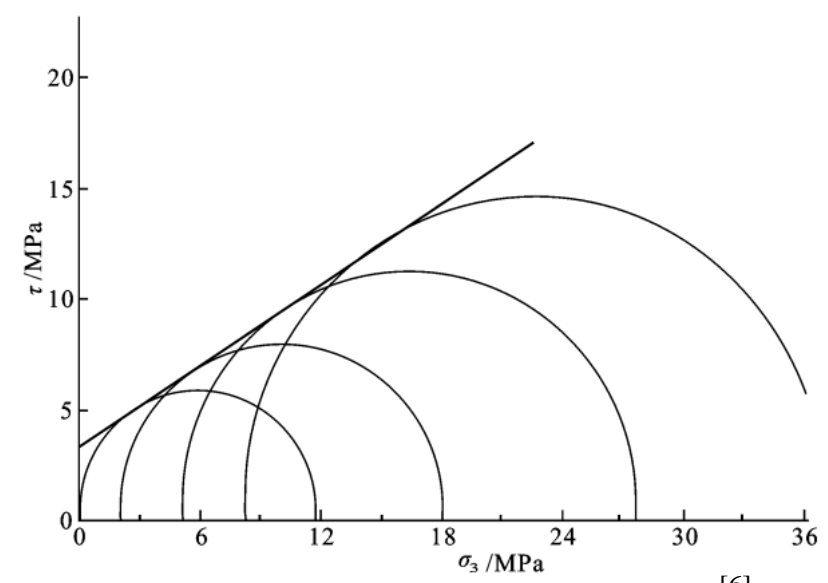

Fig.2 breccia strength envelope curve ${ }^{[6]}$

\subsubsection{Mechanical test for gravel mixtures}

Because the high content of gravel and breccia in the mixed soil, it is hard to take primary state soil sample to do indoors test. In order to analyze the mechanical strength characteristics of the mixed-soil accurately, two sets of representative gravel mixed soil were selected for shear test. Under natural state and submerged condition, exerting the normal load by 50, 100, 150, 200, 250 Kpa respectively, the test results are shown in figure $3 \sim 4$.

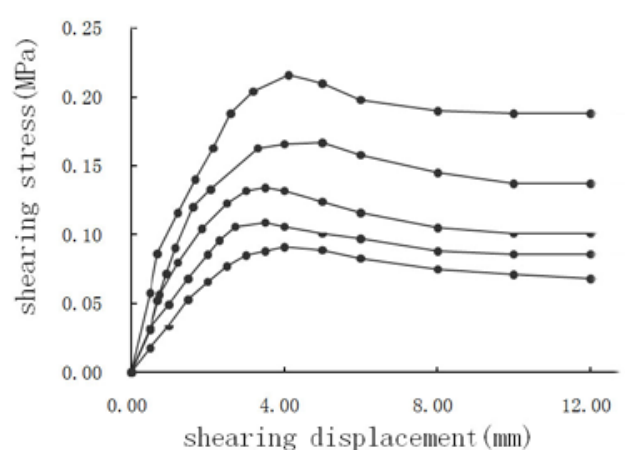

a. natural condition

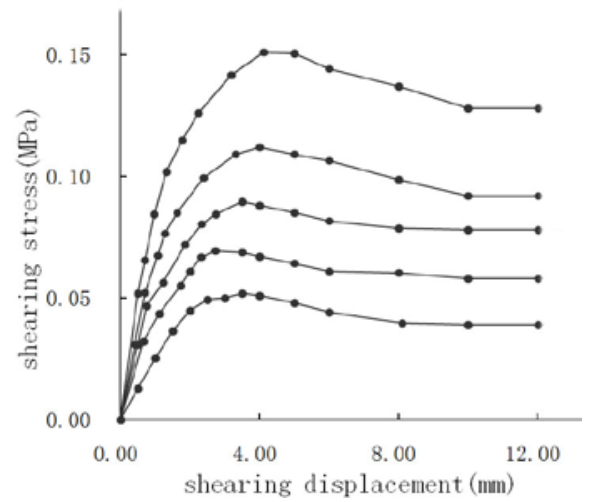

b. submerged condition

Fig.3 shearing stress and shearing displacement relationship

As we can see in the shearing stress and shearing displacement relationship diagram, under both natural state and immersion condition: in a low stress, the peak strength was obvious. As normal stress increasing, curve gradually become smooth. There is no obvious peak intensity, which shows that the soil under the condition of low stress and high stress, strain put up a softening and hardening characteristics respectively. According to the relationship between shear stress and normal stress curve, the natural state, the peak value of the soil strength parameters: $\mathrm{C}=49 \mathrm{kpa}, \Phi$ $=31.8^{\circ}$. Residual strength parameters, $\mathrm{C} '=35 \mathrm{kPa}, \Phi^{\prime}=28.6^{\circ}$, residual cohesive force reduces about $30 \%$, angle of friction decreased about $10 \%$. Under immersion condition, the peak intensity of soil parameters: $\mathrm{C}=20 \mathrm{kpa}, \Phi=26.1^{\circ}$; residual strength parameters, $\mathrm{C}^{\prime}=15 \mathrm{kPa}, \Phi^{\prime}=23^{\circ}$. Compared with the natural state, after immersion, soil strength appear sharply decrease, cohesive force was reduced by about $60 \%$; the friction angle decreasing by about $20 \%$; cohesive force mainly came from the clay cementation. Whereas the friction angle depended on the contact surface between the coarse particle roughness, which indicated that under the action of water. The degree of consolidation of soil was greatly weaken. 


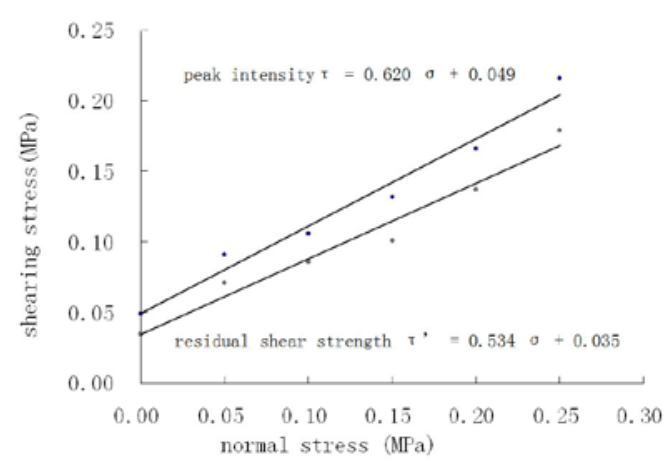

a. natural condition

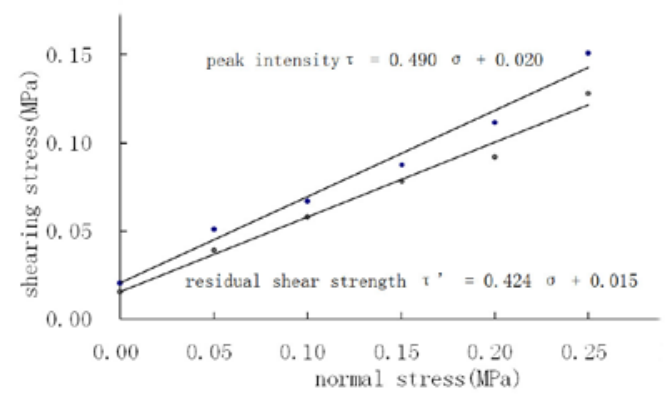

b. flooded condition

Fig.4 shearing stress and normal stress relationship

\section{Moraine layer effects on engineering}

(1) Due to the better cementation, breccia has a uniaxial compressive strength of $10.94 \sim 14.22$ MPa. Therefore it can be classified as soft rock. This kind of moraine layer has a comparatively high bearing capacity and foundation stability, but the high porosity and good permeability make it unsuitable for seepage control material.

(2) Gravel mixed soil has a comparatively high shear strength $\left(\mathrm{C}=49 \mathrm{KPa}, \Phi=31.8^{\circ}\right)$, good bearing capacity and good foundation stability under natural state. However under the effect of water, the strength will reduce more than a half, which indicates that it would be better to carry out construction in the dry season in foundation pit and slope engineering, and close in time after excavation, and adopt good waterproof and drainage measures. In addition, the uneven distribution of the particle size of gravel mixed soil may easily cause uneven settlement of building foundation.

(3) Ancient weathering crusts are distributed at the bottom of the moraine layer and between the multiphase moraine layers, and developed weak intercalation, which affect the global stability of the moraine layer slope, especially the replat type, which hung on the abrupt slope, with bed rock under the slope toe, and this kind of slop is always in the state of limit equilibrium.

\section{Results}

(1) The moraine layers of northwest of Yunnan province are the product of glacier activities, tectonic movement and climate environment interaction. The landform of the glacial and the moraine is complex and diverse. From the point of view of landscape and distribution feature, moraine layers can be divided into three types: the depression type, the terrace type and the replat type. On the another hand, moraine layers can be divided into breccia and gravel mixed-soil from the material composition, grain composition and cementation degree.

(2) The breccia is moraine consisting limestone, marble carbonate, cemented in the late calcification. It has a high uniaxial compressive strength, high bearing capacity and good stability of foundation.

(3) Gravel mixed-soil was a mixture of gravel breccia and cohesive soil, which has a high shear strength, comparatively good bearing capacity and foundation stability, yet poor water stability. The particle size and its uneven distribution may lead to poor uniformity of the foundation.

(4) The moraine layer slope has a partly stability, but there might be weak interlayers at the bottom of the moraine layer or between the moraine layers, which controls the overall stability of the slope.

\section{References}

[1] L. Shizhan, W. Ren, H. Mingjian, S. Jianhua Current status, problems and future trends of the research on engineering properties of moraine soil. Journal of Engineering Geology .19(2011):298-303. 
[2] Z. Xitao, Z. Yongshuang, Q. Yongxin, G. Changbao pleistocene glaciations along the western foot of the Yulong mountains and their relationship with the formation and development of the Jinsha river. quaternary sciences.27(2007):35-44.

[3] Peng Yi min A preliminary study of quaternary glacier problems in Lijiang district northwestern Yunnan province, journal of China university of geosciences. 15 (1990):487-494.

[4] M. Qingzhong The Quaternary glaciations in Yu-Long Mountains. Journal of Yunnan Normal University (Natural Sciences). 16 (1996): 94-104

[5] Z. Yongshuang, Q. Yongxin, W. Xianli, Y. xin, G. Changbao On the engineering geological classification of quaternary glacial deposits in southwestern mountain area of China, Journal of Engineering Geology.17(2009):581-589.

[6] Z. Yongshuang, G. Changbao , S. Jusong, Q. Yongxin , Z. Xitao Research on the engineering geological properties of moraine /out wash rocks on the west side of the Yul ong mountains. geoscience.21 ( 2007): 150-156.

[7] First Team of Regional Geological Survey Geological bureau of Yunnan. Report of regional geological survey on the people's republic of china (1: 200000) Lijiang sheet (g-47- xi) (part of geology). Kunming: geological bureau of Yunna(1977): 45-50. 